\title{
Analysis of exposure of inhabitants of Polish cities to air pollution with particulate matters with application of statistical and geostatistical tools
}

\author{
Izabela Sówka ${ }^{1, *}$, Alicja Nych $^{1}$, Dominik Kobus ${ }^{2}$, Yarolsav Bezyk ${ }^{1}$, and Maciej Zathey ${ }^{3}$ \\ ${ }^{1}$ Wroclaw University of Science and Technology, Faculty of Environmental Engineering, \\ Wyb. Wyspianskiego 27, 50-370 Wroclaw, Poland \\ 2inFAIR, www.infair.eu, dominik.kobus@infair.eu \\ ${ }^{3}$ Wroclaw University of Science and Technology, Faculty of Architecture, ul. Bolesława Prusa 53/55, \\ 50-317 Wroclaw, Poland
}

\begin{abstract}
The aim of this research was the analysis of air quality in selected Polish cities in 2008-2018 combined with health assessment based on the methodology and software of World Health Organization (AirQ +) as well as an analysis of main directions of activities aimed at improving air quality in Polish cities. The results of calculations and spatial analysis of exposure indicate the year 2010 as the one with the highest concentrations of $\mathrm{PM}_{10}$ and $\mathrm{PM}_{2.5}$, as well as Małopolskie and Śląskie Voivodships (agglomerations: Upper Silesia, Krakow and Rybnik-Jastrzębska) as the two most threatened by negative impact on human life and health. In a detailed analysis of the Wrocław agglomeration, for 2017, the estimated number of deaths of adults caused by short-term exposure to PM2.5 with a limiting concentration above $10 \mu \mathrm{g} / \mathrm{m}^{3}$ (in accordance with WHO guidelines on air quality) was over 130 people, and the estimated number of patients hospitalized because of cardiovascular and respiratory diseases due to the above exposure was 160 and 80 cases, respectively. The analysis showed more than 80 cases of asthma attacks in children with asthma caused by short-term exposure and three death cases in infants due to long-term exposure to PM10.
\end{abstract}

\section{Introduction}

Air pollution is one of the most important determinants of health. Numerous epidemiological studies have demonstrated the relationship between air pollution and a wide range of adverse health effects in general population; effects ranged from subtle subclinical effects to premature death. Some groups - for example, elderly people, children, pregnant women and people with chronic illnesses (e.g. asthma) may be more at risk and may be more at risk from exposure to air pollution. In addition, some groups may be exposed to a higher level of outdoor air pollution, for example people living near busy traffic routes or in specific occupations or socio-economic groups [1].

* Corresponding author: izabela.sowka@pwr.edu.pl 
In 2010, lung diseases were the cause of $6.9 \%$ of all hospitalizations in Poland, and death rates in 2010 due to respiratory illnesses amounted to 50.6 per 100,000 residents [2]. Because of general cardiovascular diseases, on the other hand, over one million people were treated [3]. Also, in the document "Policy paper for health care for 2014-2020" [4] published in 2014, respiratory illnesses were listed among the most important health problems of Polish citizens. They were also included in the group of health issues that generated the largest incapacity expenses in 2010 (7.5\% of the total expenditure) [5]. According to the 2012 State Health Report [6], mortality due to cardio-pulmonary syndrome and other heart diseases ( 51.5 thousand deaths in $2010-30 \%$ of deaths due to the whole circulatory causes), is higher in Poland than throughout the European Union. Death rates in 2010 due to cardiorespiratory syndrome and other heart problems were in total 134.9 per 100,000. residents [2].

The aim of this study was to analyse air quality in selected Polish cities, combined with a health assessment based on the methodology and software of World Health Organization $($ AirQ +).

\section{Research methodology}

\subsection{Air pollution monitoring data analysis}

The analysis of variability of the concentrations of selected air pollutants ( $\mathrm{PM}_{10}$ and $\left.\mathrm{PM}_{2.5}\right)$ was carried out for urban agglomerations with populations of over 250,000, according to the classification adopted in the Regulation of the Minister of Environment of August 2, 2012 on zones in which air quality is assessed (Journal of Laws from 2012, item 914). Results from measurement stations included in the National Environmental Monitoring network, recorded in the period between 2008 and 2018 were taken into account and Air Quality Portal of the Chief Inspectorate for Environmental Protection was the source of data used for calculations. Data from 2018 should be treated as not finally approved yet by bodies responsible for monitoring.

The analysis took into account data from an urban and suburban background and industrial stations (located within agglomeration boundaries). Due to the significantly limited spatial representativeness, uneven distribution in agglomerations and lack of continuity in the period covered by the analysis, data from traffic stations was omitted. Prior to the processing of data, they were selected due to the quality level, as well as applied measurement methodologies. Annual series of measurement results with a completeness of at least $75 \%$, obtained by the manual gravimetric method (being the reference method), as well as automatic methods in the absence of manual measurements in a given location were included. For the purposes of analysis, the 1-hour data series were aggregated to 24-hour data, with the condition of minimum $75 \%$ completeness of data in the day. Then, for each agglomeration, daily indicators for individual pollutants were calculated: daily average and maximum daily mean values for each day for all stations in the agglomeration. For each agglomeration an annual index was calculated, being an arithmetic mean of daily average indicators.

\subsection{WHO model}

The analysis of the impact (both short- and long-term) of selected air pollutants on health and lives of exposed people was carried out using AirQ + software developed by WHO. The effect of exposure to excessive occurrence in atmospheric air of particulate matter $\left(\mathrm{PM}_{2.5}\right.$ and $\mathrm{PM}_{10}$ ) has been analysed. In particular, for 12 agglomerations throughout Poland, the effect of long-term $\mathrm{PM}_{2.5}$ exposure on the total mortality was analysed. In addition, for the same agglomerations, the effect of exposure to $\mathrm{PM}_{2.5}$ on cases of hospital admission for 
cardiovascular (HACD) and respiratory diseases (HARD) was evaluated. Results of concentrations of individual pollutants from the period between 2008 and 2018 were used for calculations. Additionally, for the Wrocław agglomeration, for 2017, analysis of long-term impact from $\mathrm{PM}_{10}$ dust on post neonatal infant mortality and short-term impact on the occurrence of asthma attacks in children with asthma was carried out. Moreover, effects of short-term $\mathrm{PM}_{2.5}$ exposure on adults mortality, as well as HACD and HARD were analysed. Statistical data on population, deaths and baselines for hospitalization in the analysed areas was taken from the Central Statistical Office and Ministry of Health. The default values in the software were used for relative risk (which estimates the relationship between exposure and health problems and indicates the probability of disease development in the exposed group, compared to those who are not exposed), as well as the value of the limit concentration below which health impact is not analysed. Table 1 presents the relative risk for each health effect analysed in this paper.

Table 1. Relative risk ( $95 \%$ confidence interval) and used for investigating PM health effects.

\begin{tabular}{|l|c|}
\hline \multicolumn{1}{|c|}{ Health effect } & Relative risk (95\% CI) \\
\hline Short term effect $\mathrm{PM}_{2.5}$ Mortality, all causes (adults age 30+ years) & $\mathbf{1 . 0 1 2 3}(1.0045-1.0201)$ \\
\hline Short term effect $\mathrm{PM}_{2.5}$ Hospital admission for cardiovascular diseases & $\mathbf{1 . 0 0 9 1}(1.0017-1.0166)$ \\
\hline Short term effect $\mathrm{PM}_{2.5}$ Hospital admission for respiratory diseases & $\mathbf{1 . 0 0 8}(1.0048-1.0112)$ \\
\hline Short term effect $\mathrm{PM}_{10}$ Incidence of asthma symptoms in asthmatic children & $\mathbf{1 . 0 2 8}(1.006-1.051)$ \\
\hline Long term effect $\mathrm{PM}_{10}$ Post neonatal infant Mortality, all cause & $\mathbf{1 . 0 4}(1.02-1.07)$ \\
\hline Long term effect $\mathrm{PM}_{2.5}$ Mortality, all causes (adults age 30+ years) & $\mathbf{1 . 0 6 2}(1.04-1.083)$ \\
\hline
\end{tabular}

\subsection{Geostatistical analysis}

A geostatistical analysis is a very useful approach that allows providing accessible information related to the ambient air quality monitoring network. Then, the geographical information system (GIS) as a set of powerful techniques of geoprocessing, mapping and spatial analysis is capable in terms of distribution and spatial patterns for each air pollutants [7].

The GIS estimated air pollution surfaces can be certainly useful for further analysis of the air pollution series in the urban area at different time scales and prediction purposes of air pollutants for exposure studies.GIS was used in the work to visualize the results of statistical analyses of estimated number of attributable cases of total mortality caused by long-term exposure on $\mathrm{PM}_{2.5}$ in 2010 against the average of 2008-2018 and the estimated number of attributable cases of patients hospitalized for cardiovascular (HACD) and respiratory (HARD) diseases in Poland in 2010 caused by short-term exposure on $\mathrm{PM}_{2.5}$.

\section{Research results and discussion}

\subsection{Characteristics of dust pollution in selected Polish cities}

Cities in Poland, including the largest agglomerations, show very high diversity in terms of air quality. This also applies to particulate matter, the concentration of which was analysed. The areas with lower concentrations of this pollution include the agglomerations: Trójmiejska and Szczecińska, while the highest concentrations occur in RybnickoJastrzębska, Górnośląska and Krakowska. The annual variability course of $\mathrm{PM}_{10}$ and $\mathrm{PM}_{2.5}$ concentrations indicates a declining trend, with the occurrence of peaks in 2010 in most cities (Fig. 1. - example for $\mathrm{PM}_{2.5}$ ). This year was characterized, among other things, by such meteorological conditions in winter, that are conducive to an increased emission of 
particulate matter, mainly from the domestic heating sources - e.g. a large number of days with the minimum temperature below $10^{\circ} \mathrm{C}$ [8]. Such conditions, combined with low wind speed and the occurrence of the temperature inversion phenomenon, lead to an increase in emission and weakening dispersion conditions and as a consequence to higher pollution. The occurrence of smog episodes is quite common in autumn and winter in Poland, including in the analysed agglomerations [9-11].

In the last four years, a stable situation with respect to the average concentration of $\mathrm{PM}_{2.5}$ can be observed in most cities, even with increases in some agglomerations.

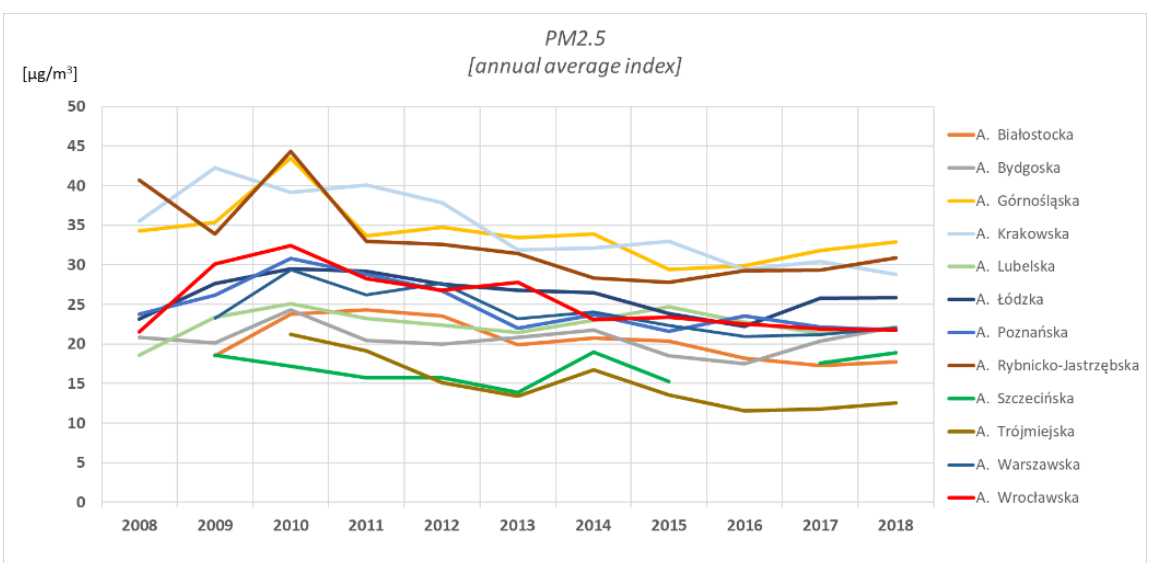

Fig. 1. Variability of annual $\mathrm{PM}_{2.5}$ indices in agglomerations in 2008-2018 (source: own elaboration based on data from the State Environmental Monitoring).

$\mathrm{PM}_{10}$ and $\mathrm{PM}_{2.5}$ concentrations for all cities show large seasonal, weekly and daily variations. An example of data from 2017 for one of the stations located in the Wrocław Agglomeration is shown in Figure 2. January and February were characterized by very high concentrations, including deep episodes - average concentrations significantly differed in this period from the rest of the year. The concentrations on weekend days are noticeably lower, which can be attributed to smaller car traffic that impacts this station. Such an influence is also indicated by analysis of daily variation, where traffic peaks are clearly visible, but they are clearer (especially in the morning) for the larger fraction of measured dust $\left(\mathrm{PM}_{10}\right)$.
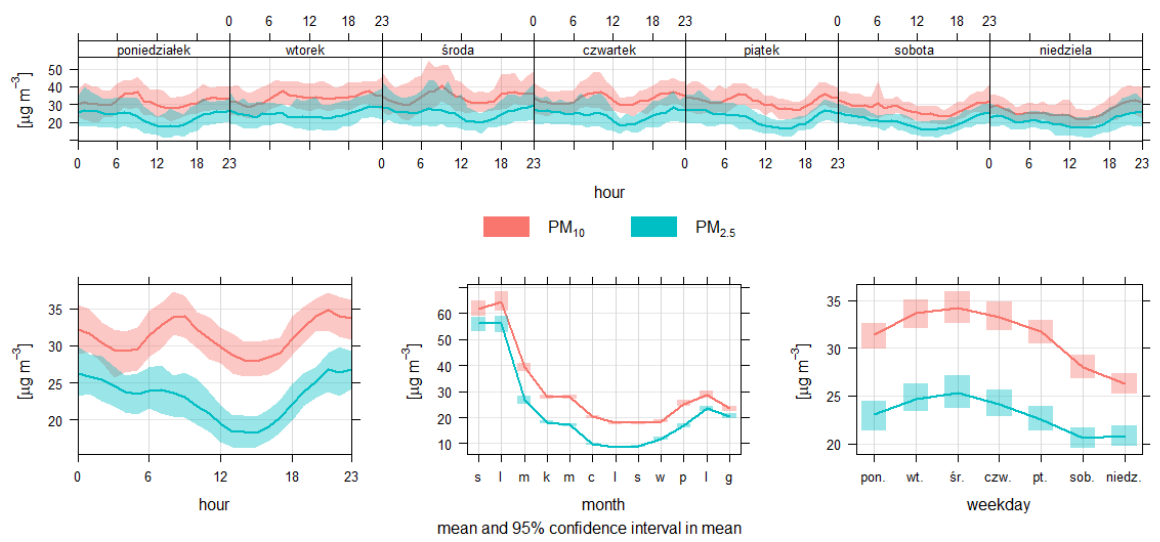

Fig. 2. Seasonal, weekly and daily $\mathrm{PM}_{10}$ concentration variability at the Wrocław-Korzeniowskiego station in 2017 (source: own state-owned monitoring based on the State Environmental Monitoring). 


\subsection{Short and long-term exposure of inhabitants of Polish cities to dust concentrations $\mathrm{PM}_{2.5}$ and $\mathrm{PM}_{10}$}

The results of calculations of the estimated number of deaths caused by long-term exposure to $\mathrm{PM}_{2.5}$ above $10 \mu \mathrm{g} / \mathrm{m}^{3}$ and the results of calculations of the estimated number of patients hospitalized for cardiovascular (HACD) and respiratory system diseases (HARD) in 2010 due to short-term exposure on $\mathrm{PM}_{2.5}$ are showed on Figures 3 and 4.

Due to the highest average concentration in analysed period, the risk for 2010 was compared to the medium risk in 2008-2018. As predicted, in 2010 the estimated risk was higher. For the majority of agglomerations, this risk increased by more than half. The exception here were the Wrocław and Trójmiasto agglomerations, where the risk has increased on average two and three times, respectively. However, the highest estimated risk attributed to total mortality due to long-term exposure to PM2.5 in 2010 was calculated for the Górnośląska, Krakowska and Rybnicko-Jastrzębska agglomerations: $22.44 \%, 19.11 \%$ and $18.91 \%$, respectively. The number of deaths that could be avoided was greatest in the agglomerations of Górny Śląsk, Warsaw and Krakow, and amounted to 3962, 2419 and 1422 , respectively (Figure 3). Moreover, the estimated risk for both HACD and HARD is greatest in the Gornośląska and Krakowska agglomerations, and is respectively 3.84\%, 3.23\% for HACD and $3.28 \%$, respectively, and $2.84 \%$ for HARD. The largest number of cases potentially excessively hospitalized due to the above health problems were calculated for the Upper Silesian and Warsaw agglomerations: 3222 and 1850 respectively for HACD and 1256 and 721 for HARD (Figure 4).

An analysis of calculations of the estimated number of cases assigned to specific contamination and health effects, which could potentially be avoided in short-term exposure to $\mathrm{PM}_{10}$ and $\mathrm{PM}_{2.5}$, lowering their concentration below $10 \mu \mathrm{g} / \mathrm{m}^{3}$ in 2017 in Wrockaw agglomeration showed that reduction of dust concentration PM2.5 would give the most measurable results in the number of people hospitalized for cardiovascular diseases (over 160 cases), compared to the impact on hospitalizations due to the respiratory ones (about 80 hospitalizations) and total mortality in people over 30 years of age (about 130 deaths). In addition, an estimated more than 80 cases of asthma attacks in children with asthma would potentially avoid reducing $\mathrm{PM}_{10}$. The long-term effect of PM10 dust on postneonatal infant mortality in this period (2017) is 3 excess deaths.

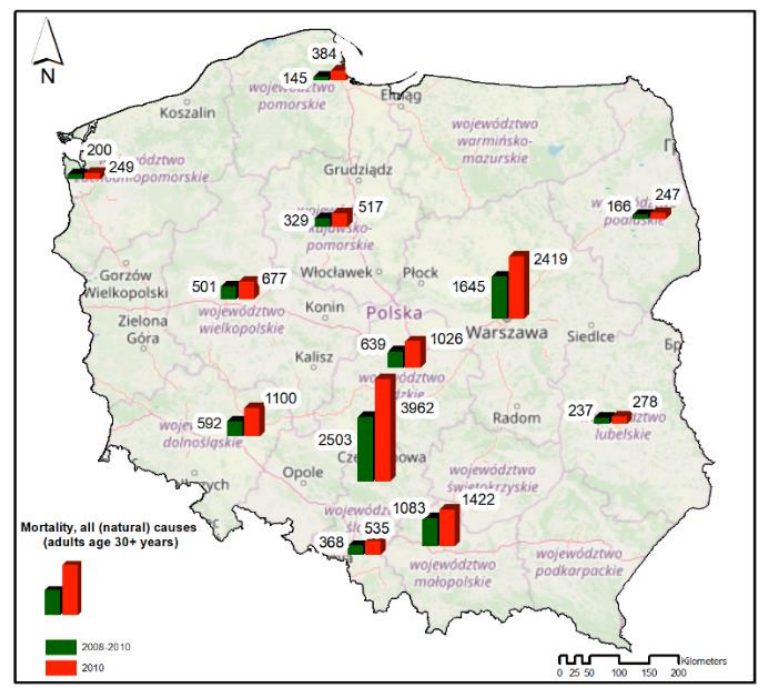

Fig. 3. Comparison of estimated number of attributable cases of total mortality caused by long-term exposure on $\mathrm{PM}_{2.5}$ in 2010 against the medium of 2008-2018. 


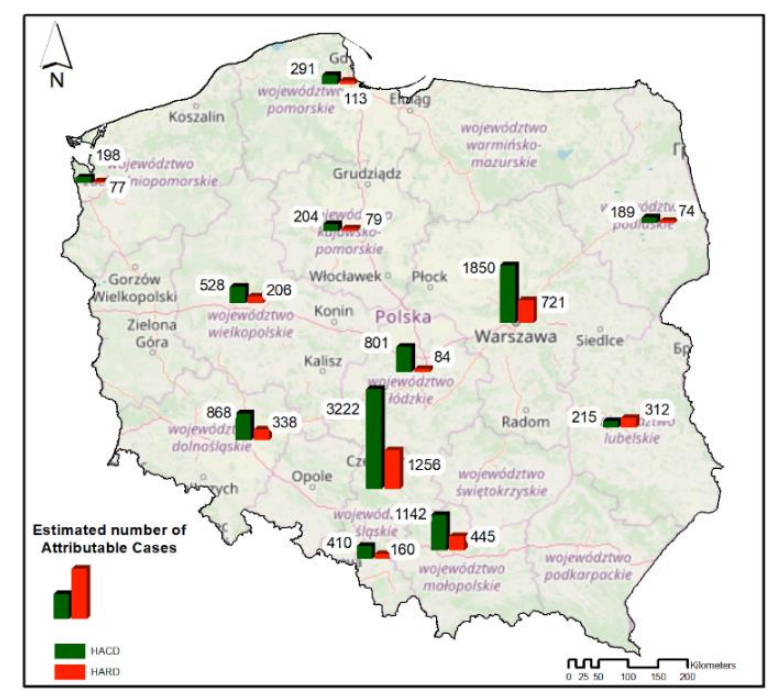

Fig. 4. Estimated number of attributable cases of patients hospitalized for cardiovascular (HACD) and respiratory (HARD) diseases in Poland in 2010 caused by short-term exposure on $\mathrm{PM}_{2.5}$.

\subsection{Analysis of main directions of activities aimed at improving air quality in Polish cities}

Formal activities related to the improvement of air quality in Polish cities depend mainly on legal solutions and subsequent financing of their effects. In this context, cities use the law laid down by the Polish national parliament and regional councils. Local activities, being a commune or urban initiative, are complementary. Actions such as: a day without the car, tree planting or dissemination of information about threats resulting from exceeding limit values of air pollution are primarily aimed at educating and shaping social attitudes. However, they do not eliminate the causes of pollution.

In order to achieve the observance of environmental quality standards, in Poland, based on the Act - Environmental Protection Law (Journal of Laws 2001 No. 62 item 627 with later amendments), air protection programs adopted by way of a resolution by voivodship parliaments are created. They contain recommendations being an obligation addressed mainly to local governments and, therefore, also to cities. Unfortunately, this mechanism is ineffective as evidenced by the state of atmospheric pollution and the need to introduce additional restrictions. Therefore, on the basis of the amendment to the Act - Environmental Protection Law, which was passed on November 12, 2015, regional councils gained the possibility of introducing restrictions and prohibitions on the operation of installations in which fuels are burned - adoption of the so-called anti-smog resolutions (Table 3).

In parallel to the preparation of the anti-smog resolutions, social pressure has caused the preparation of system solutions at a central level in Poland. The ordinance of the Minister of Development and Finance on requirements for solid fuel boilers has been adopted, which formally eliminated from 01.07.2018 the sale of boilers that do not comply with EN 303-5: 2012. The second significant regulation, issued by the Minister of Energy, defines the quality requirements for solid fuels. It uses a two-year grace period for the use of coal fines below $3 \mathrm{~mm}$ in diameter. In this respect, the national provision is more liberal than regional solutions. This results in maintaining a trade in fuels whose combustion is prohibited by regulations adopted by the regional councils. This paradox sustains illegal combustion of high-emission solid fuels by 30 June 2020 . 
Table 3. A list of voivodships in which the regional councils have introduced restrictions and prohibitions regarding the operation of installations in which fuels are burned pursuant to art. 96 of the Act - Environmental Protection Law (drawn up on the basis of resolutions of regional councils included in the analysis).

\begin{tabular}{|c|c|c|c|c|}
\hline & Voivodship & $\begin{array}{l}\text { Separate } \\
\text { regulations } \\
\text { for cities }\end{array}$ & $\begin{array}{l}\text { The date } \\
\text { of the most } \\
\text { stringent } \\
\text { prohibition }\end{array}$ & $\begin{array}{l}\text { Requirements for fuels and } \\
\text { installations }\end{array}$ \\
\hline 1. & dolnośląskie & \multicolumn{3}{|c|}{ Resolution adopted on 30.11 .2017} \\
\hline & & Wroclaw & 01.07 .2028 & $\begin{array}{c}\text { The target total elimination of solid } \\
\text { fuels. }\end{array}$ \\
\hline & & Spas & 01.07 .2028 & $\begin{array}{l}\text { Target total elimination of solid } \\
\text { fuels in seven locations, in four } \\
\text { locations permitted installations in } \\
\text { accordance with EC Regulation } \\
\text { (EU) } 2015 / 1185 \text { with regard to } \\
\text { ecodesign requirements. }\end{array}$ \\
\hline 2. & lubuskie & \multicolumn{3}{|c|}{ Resolution adopted on 18.06 .2018} \\
\hline & & $\begin{array}{c}\text { Gorzów } \\
\text { Wielkopolski } \\
\end{array}$ & 01.01.2023 & $\begin{array}{c}\text { Class } 5 \text { installations according to } \\
\text { PN-EN 303-5: 2012. }\end{array}$ \\
\hline & & $\begin{array}{c}\text { Zielona } \\
\text { Góra } \\
\end{array}$ & 01.01 .2023 & $\begin{array}{c}\text { Class } 5 \text { installations according to } \\
\text { PN-EN 303-5: 2012. } \\
\end{array}$ \\
\hline 3. & łódzkie & \multicolumn{3}{|c|}{ Resolution adopted on 24.10 .2017} \\
\hline 4. & małopolskie & \multicolumn{3}{|c|}{ Resolution adopted on 23.01.2017 } \\
\hline & & Kraków & 01.09.2019 & $\begin{array}{c}\text { The target total elimination of solid } \\
\text { fuels. }\end{array}$ \\
\hline 5. & mazowieckie & \multicolumn{3}{|c|}{ Resolution adopted on 24.10 .2017} \\
\hline 6. & opolskie & \multicolumn{3}{|c|}{ Resolution adopted on 26.09.2017 } \\
\hline 7. & podkarpackie & \multicolumn{3}{|c|}{ Resolution adopted on 23.04 .2018} \\
\hline 8. & śląskie & \multicolumn{3}{|c|}{ Resolution adopted on 07.04.2017 } \\
\hline 9. & wielkopolskie & \multicolumn{3}{|c|}{ Resolution adopted on 18.12.2017 } \\
\hline & & Poznań & 01.01.2028 & $\begin{array}{c}\text { Installations in accordance with the } \\
\text { EC Regulation (EU) } 2015 / 1185 \\
\text { with regard to ecodesign } \\
\text { requirements. }\end{array}$ \\
\hline & & Kalisz & 01.01.2028 & $\begin{array}{c}\text { Class } 5 \text { installations according to } \\
\text { PN-EN 303-5: 2012 } \\
\end{array}$ \\
\hline 10. & zachodniopomorskie & \multicolumn{3}{|c|}{ Resolution adopted on 26.09 .2018} \\
\hline
\end{tabular}

\section{Conclusions}

The analysis of research results and calculations carried out indicate higher concentrations of dust contamination, which may contribute to the deterioration of the quality of life of the inhabitants of Polish cities. Reduction of air pollution in Polish cities should therefore become a priority in activities in the field of environmental protection in Poland.

A real improvement of air quality in cities will be possible only after the transformation of heating systems and a widespread use of zero-emission or low-emission heat production technology with a simultaneous improvement of energy efficiency in housing, housing estates and transport systems. For this purpose, a radical change in the energy policy of the state is needed. In this context, the energy policy and the air quality policy pursued by regions and cities will be a secondary activity. Programs for co-financing changes in heat sources, which are mainly responsible for air pollution, should be considered as the initial stage of converting the heat protection system in Poland. 
The investigations were co-financed within the framework of the order No. 0401/00581/18.

\section{References}

1. WHO Regional Office for Europe, Health risk assessment of air pollution - general principles (Copenhagen, 2016)

2. Ministerstwo Zdrowia, Program Polityki Zdrowotnej (2017)

3. Ministertwo Zdrowia, Narodowy Program Wyrównywania Dostępności do Profilaktyki i Leczenia Chorób Układu Sercowo-Naczyniowego POLKARD na lata 2013-2016 (2014)

4. Ministerstwo Zdrowia, Krajowe ramy strategiczne (2015)

5. E. Karczewicz, A. Kania, Wydatki na świadczenia z ubezpieczeń społecznych związane z niezdolnościa do pracy w 2010 r. (2012)

6. B. Wojtyniak, P. Goryński, B. Moskalewicz, Sytuacja zdrowotna ludności Polski i jej uwarunkowania (pod red. NIZP-PZH, Warszawa, 2011)

7. J. Gulliver, K. de Hoogh, D. Fecht, D. Vienneau, D. Briggs, Atmos. Environ, 45, 7072-7080 (2011)

8. A. Chlebowska-Styś, I. Sówka, D. Kobus, Ł. Pachurka, E3S Web of Conferences 17, 1-8 (2017)

9. D. Kobus, A. Nych, I. Sówka, E3S Web of Conferences 44, 00070 (2018)

10. J. Iwanek, J. Strużewska, J. Kamiński, P. Durka, D. Kobus, J. Kostrzewa, T. Pecka, Analiza wybranych epizodów wysokich stężé pytu PM10 z lat 2013-2016, Etap II, Epizody z lat 2015-2016 The work done for CIEP (Instytut Ochrony Środowiska Państwowy Instytut Badawczy: IOŚ PIB, 2017)

11. K. Juda-Rezler, B. Toczko (ed.), Pyty drobne $w$ atmosferze. Kompendium wiedzy o zanieczyszczeniu powietrza pyłem zawieszonym w Polsce (Inspekcja Ochrony Środowiska: IOŚ, Biblioteka Monitoringu Środowiska, Warszawa, 2016)

12. Rozporządzenie Ministra Rozwoju i Finansów z dnia 1 sierpnia 2017 r. w sprawie wymagań dla kotłów na paliwo stałe

13. Rozporządzenie Ministra Energii z dnia 27 września 2018 r. w sprawie wymagań jakościowych dla paliw stałych

14. Ustawa - Prawo ochrony środowiska Dz. U. 2001 Nr 62 poz. 627 z pózn. zm. 